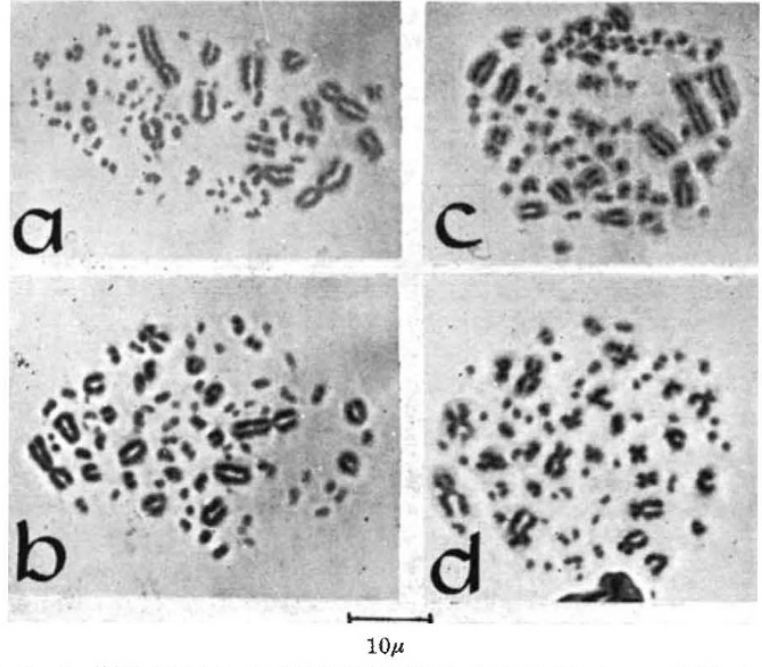

Fig. 1. Photographs of avian metaphase chromosomes. a, Chicken, colchicus torquatus); $c$, robin, female (Turdus migratorius); $d$, sparrow, male (Passer domesticus)

This relatively simple method, which requires no elaborate equipment, may enable a number of investigators to undertake cytogenetic investigations of avian species. The quality of the preparations that has been obtained can be seen in Fig. 1.

N. S. Fechretmer

W. P. JAFTE*

Departments of Dairy and Poultry Science,

Ohio State University,

Columbus, Ohio.

* On leave from University of Bristol.

${ }^{1}$ Shoffner, R. N., World's Poultry Sci. J., 21, 157 (1965).

${ }^{2}$ Moorhead, P. S., Nowell, P. C., Mellman, J., Battips, D. M., and Hungerford, 1). A., Exp. Cell Res., 20, 613 (1960).

\section{Frequency of Colour Blindness among East Kentish Children}

AN investigation of the frequency of colour blindness among East Kentish children was made in connexion with research sponsored by the Department of Child Develop. ment, Institute of Education, University of London. The Ishihara Test (second edition: 24 plates) was used under north daylight conditions, and all the children in five schools were tested. Two of the schools were in the city of Canterbury, two in agricultural communities and one in a Kentish coalfield village. The children ranged in age from 4.5 to $11.0+$ years. "Colour blind" responses to 12/16 plates of figures and/or all the "path tracing" plates were required for a diagnosis of colour blindness. The frequencies found were as shown in Table 1.

\begin{tabular}{lcc}
\multicolumn{2}{c}{ Table 1 } & \\
& Boys & Girls \\
Number tested & 505 & 450 \\
Colour blind & 17 & 0 \\
Percentage colour blind & 3.37 & 0
\end{tabular}

The children had been tested with the Kent (Standardised) Tests. The range of general ability among the colour blind boys ran from 78 I.Q. to 134 I.Q., and no relationship was found between either educational ratio or intelligence quotient and colour blindness.

The frequency of $3 \cdot 37$ per cent of red-green blind boys in East Kent is very low, but accords with the findings of Vernon and Straker ${ }^{1}$, who reported $\mathbf{3 \cdot 5 5}$ per cent for
Edinburgh, $3 \cdot 26$ per cent for Chesterfield and 4.37 per cent for Romford. Kherumian and Pickford reported 4.12 per cent in the Vosges and Moselle. These are the lowest frequencies reported for Great Britain and France, and they occur in the north and east of Britain and in those parts of France which have the poorest soils and are most romoved from the Mediterranean and English Channel coasts, as was pointed out by Post $^{3}$ and Pickford ${ }^{4}$, in their observations on the possible relaxation of natural selection against colour blindness under the conditions of civilization.

In the present investigation the expected frequencies of colour blind girls would be less than 3.37 per cent ${ }^{2}$, namely, about one in 1,000 or fewer, and it is not surprising that none was found in a sample of 450 girls.

I thank Prof. R. W. Pickford and Miss Mary Waddington for their assistance.

JOHN RICHES

2 Nailbourne Close,

Kingston,

Canterbury.

${ }^{1}$ Vernon, P. E., and Straker, A., Nature, 152, 690 (1943).

¿ Kherumian, R., and Pickford, R. W., Héredité et Fréquence des Dyschromatopsies (Vigot, Paris, 1959).

${ }^{3}$ Post, R. H., Eugen. Quart., 9, 131 (1062).

4 Pickford, R. W., Eugen. Rev., 55, 97 (1963).

\section{RADIOBIOLOGY}

\section{Assessment of Body Content of Radioactive Strontium following Contamination in Adult Men}

ASSESSMENT of the body content of humans following an accident with radioactive strontium, particularly with strontium-89 or strontium-90, is one of vital concern. Even if equipment for body radioactivity measurement is available, its relatively low sensitivity for these isotopes makes it important to have other rapid and reliable means of estimating the body content. One of us ${ }^{1}$ presented a simple relationship between the cumulative urinary excretion of radioactive strontium over 21 days, $\Sigma_{0}^{21} U$, and the injected dose $R_{0}$ :

$$
R_{0}=\frac{\Sigma_{0}^{21} U}{0 \cdot 6}
$$

It was also shown that following a chronic ingestion of radioactive strontium there was a simple relationship between $\Sigma_{0}^{21} U$ and the systemic retention at the time of the last ingestion.

It has been pointed out by Macdonald et al. ${ }^{2}$ that complete collection of urine over 3 weeks has practical diffculties and the inevitable delay in assessment of the body content of radioactive strontium is undesirable. Additional data from experiments in which the gamma-ray emitter, strontium-85, was administered to volunteers from the Radiobiological Research Unit have prompted us to give the problem further consideration. In Tables 1 and 2 we have compared the urinary excretion of radioactive strontium in 5,10 and 21 days as a percentage of systemic content, $R_{0}$. For the intravenous administrations (Table 1) the original dose was taken as the value of $R_{0}$, while for the chronic ingestion (Table 2) $R$ was derived from body radioactivity measurements for each subject ${ }^{3}$.

It will be seen that the more complete data support the original empirical equation (1). However, the gain in accuracy by extending the urinary collection to 21 days (as judged by the standard errors of the mean values) is small. To make the assessment of body content of radioactive strontium more rapid, it is suggested that the modified formula $R_{0}=\frac{\Sigma_{n}^{5} U}{0.5}$ following intravenous injection is sufficiently exact for the present requirements. 